\title{
The characteristics of atmospheric brown carbon in Xi'an, inland China: sources, size distributions and optical properties
}

\author{
Can $\mathrm{Wu}^{1,2}$, Gehui Wang ${ }^{1,2,3,4}$, Jin $\mathrm{Li}^{2}$, Jianjun $\mathrm{Li}^{2}$, Cong $\mathrm{Cao}^{2}$, Shuangshuang $\mathrm{Ge}^{1}$, Yuning $\mathrm{Xie}^{1}$, Jianmin Chen ${ }^{3,5}$, \\ Xingru Li ${ }^{1,6}$, Guoyan Xue ${ }^{1}$, Xinpei Wang ${ }^{1}$, Zhuyu $\mathrm{Zhao}^{7}$, and Fang $\mathrm{Cao}^{7}$ \\ ${ }^{1}$ Key Lab of Geographic Information Science of the Ministry of Education, School of Geographic Sciences, \\ East China Normal University, Shanghai 210062, China \\ ${ }^{2}$ Key Lab of Aerosol Physics and Chemistry, State Key Laboratory of Loess and Quaternary Geology, \\ Institute of Earth Environment, Chinese Academy of Sciences, Xi'an 710061, China \\ ${ }^{3}$ Institute of Eco-Chongming, 3663 North Zhongshan Road, Shanghai 200062, China \\ ${ }^{4}$ CAS Center for Excellence in Regional Atmospheric Environment, Institute of Urban Environment, \\ Chinese Academy of Sciences, Xiamen 361021, China \\ ${ }^{5}$ Department of Environmental Science and Technology, Fudan University, Shanghai 200433, China \\ ${ }^{6}$ Department of Chemistry, Analytical and Testing Center, Capital Normal University, Beijing 100048, China \\ ${ }^{7}$ Yale-NUIST Center on Atmospheric Environment, Nanjing University of Information Science \& Technology, \\ Nanjing 210044, China
}

Correspondence: Gehui Wang (ghwang@geo.ecnu.edu.cn)

Received: 11 July 2019 - Discussion started: 26 August 2019

Revised: 25 December 2019 - Accepted: 23 January 2020 - Published: 21 February 2020

\begin{abstract}
To investigate the characteristics of atmospheric brown carbon $(\mathrm{BrC})$ in the semiarid region of East Asia, $\mathrm{PM}_{2.5}$ and size-resolved particles in the urban atmosphere of Xi'an, inland China, during the winter and summer of 2017 were collected and analyzed for optical properties and chemical compositions. Methanol extracts ( $\mathrm{MeOH}$ extracts) were more light-absorbing than water extracts $\left(\mathrm{H}_{2} \mathrm{O}\right.$ extracts) in the optical wavelength of $300-600 \mathrm{~nm}$ and well correlated with nitrophenols, polycyclic aromatic hydrocarbons (PAHs) and oxygenated PAHs $(r>0.78)$. The light absorptions $\left(\mathrm{abs}_{\lambda=365 \mathrm{~nm}}\right)$ of $\mathrm{H}_{2} \mathrm{O}$ extracts and $\mathrm{MeOH}$ extracts in winter were $28 \pm 16$ and $49 \pm 32 \mathrm{M} \mathrm{m}^{-1}$, respectively, which are about 10 times higher than those in summer, mainly due to the enhanced emissions from biomass burning for house heating. Water-extracted $\mathrm{BrC}$ predominately occurred in the fine mode $(<2.1 \mu \mathrm{m})$ during winter and summer, accounting for $81 \%$ and $65 \%$ of the total absorption of $\mathrm{BrC}$, respectively. The light absorption and stable carbon isotope composition measurements showed an increasing ratio of $\operatorname{abs}_{\lambda=365 \mathrm{~nm}}-\mathrm{MeOH}$ to $\mathrm{abs}_{\lambda}=550 \mathrm{~nm}-\mathrm{EC}$ along with an enrichment of ${ }^{13} \mathrm{C}$ in $\mathrm{PM}_{2.5}$ during the haze development, indicating an accumulation of secondarily formed $\mathrm{BrC}$ (e.g., nitro-
\end{abstract}

phenols) in the aerosol aging process. Positive matrix factorization (PMF) analysis showed that biomass burning, fossil fuel combustion, secondary formation, and fugitive dust are the major sources of $\mathrm{BrC}$ in the city, accounting for $55 \%$, $19 \%, 16 \%$, and $10 \%$ of the total $\mathrm{BrC}$ of $\mathrm{PM}_{2.5}$, respectively.

\section{Introduction}

Brown carbon $(\mathrm{BrC})$ is a vital fraction of carbonaceous aerosols and exhibits strong absorption ability from the nearultraviolet (UV) to visible light region. Thus, it has been given extensive investigation in the recent decades (Laskin et al., 2015; Yan et al., 2018; Gustafsson et al., 2009). BrC has significant impact on climate change directly by absorbing solar radiation and indirectly by accelerating snowmelt and affecting the albedo (Qian et al., 2015; Andreae and Ramanathan, 2013). Based on the remote sensing observations and chemical transport models (Chung et al., 2012; Wang et al., 2014; Jo et al., 2016), a non-negligible positive radiative forcing by $\mathrm{BrC}$ was found on a global scale with a range from 0.1 to $0.6 \mathrm{~W} \mathrm{~m}^{-2}$. Beyond that, $\mathrm{BrC}$ also influences atmo- 
spheric chemistry and human health. For example, BrC can shield polycyclic aromatic hydrocarbons (PAHs) from being oxidized and thus substantially elevate lung cancer risk from PAHs (Hsu et al., 2014; Yan et al., 2018).

The sources of $\mathrm{BrC}$ are complicated since it can be primarily emitted from incomplete combustion of carboncontaining materials (e.g., biomass, coal and petroleum products) and secondarily derived from aqueous-phase reaction (Sun et al., 2017; Gilardoni et al., 2016; Xie et al., 2018; Nakayama et al., 2013). Biomass burning was found to be a major source of $\mathrm{BrC}$ (Chen and Bond, 2010; Chakrabarty et al., 2010; Saleh et al., 2014), because lignin is of an unsaturated benzene-like structure, which is a chromophore group. Previous studies found that $\mathrm{BrC}$ also comes from secondary sources by forming chromophores during the aerosol aging process, e.g., high- $\mathrm{NO}_{x}$ photooxidation (Liu et al., 2016; Xie et al., 2017), ozonolysis of aromatic precursors (Lee et al., 2014), and aqueous-phase photochemical oxidation and polymerization (Smith et al., 2014; Flores et al., 2014; Bones et al., 2010). BrC products account for a very small weight fraction of organic aerosol (OA) but have a significant effect on OA optical properties. For example, nitroaromatic compounds generated by photooxidation of toluene under high$\mathrm{NO}_{x}$ conditions may account for $40 \%-60 \%$ of the total light absorption of toluene SOA (Lin et al., 2015).

Multiple approaches have been developed to quantify the light absorption properties of $\mathrm{BrC}$ (Moosmuller et al., 2009), and a common and sensitive approach is the direct measurement of spectrophotometric properties of aerosol water or filter extracts by using optical instrumentation. The advantage of this method can avert interference from insoluble absorption material (e.g., black carbon) (Cheng et al., 2016; Shen et al., 2017) and supply a high-resolution spectrum over a wide wavelength coverage. Furthermore, it is favorable for characterization of $\mathrm{BrC}$ light-absorbing components by combing with other analytical techniques, such as mass spectrometry (MS) (Laskin et al., 2015; Corr et al., 2012; Satish et al., 2017).

Many studies have been conducted on the $\mathrm{BrC}$ optical properties in China, but most of those were based on $\mathrm{PM}_{2.5}$ and $\mathrm{PM}_{10}$ sample collection and focused on the bulk aerosol optical properties with no information on the size distributions (Shen et al., 2017; Huang et al., 2018). Xi' an is a metropolitan city located in Guanzhong Basin of inland China, which is a typical semiarid region in East Asia and has been suffering from serious particle pollution due to the large emission of anthropogenic pollutants (Wu et al., 2018; Wang et al., 2016; Wu et al., 2019), especially intensive coal combustion and biomass burning in winter for house heating (Wang et al., 2017). In this study, both $\mathrm{PM}_{2.5}$ and sizesegregated aerosol samples in Xi'an were collected during the 2017 winter and summer and analyzed for the characteristics of $\mathrm{BrC}$. We firstly investigated the seasonal variations in chemical composition and light absorption of $\mathrm{BrC}$ in the city, then discussed the size distribution of $\mathrm{BrC}$ and the im- pact of aerosol aging process on $\mathrm{BrC}$, and finally quantified its source contributions.

\section{Experiment}

\subsection{Sample collection}

Aerosol samples were collected on a day-night basis each for $12 \mathrm{~h}$ by using a high-volume $\left(\sim 1.13 \mathrm{~m}^{3} \mathrm{~min}^{-1}\right)$ air sampler (Tisch Environmental, Inc., OH, USA) from 31 December 2016 to 22 January 2017 (in winter) and from 18 July to 6 August 2017 (in summer). The sampler was installed on the roof of a three-story building on the campus of the Institute of Earth Environment, CAS $\left(34.22^{\circ} \mathrm{N}, 108.88^{\circ} \mathrm{E}\right)$, which is located at the urban center of Xi' an, inland China. Meanwhile, size-resolved aerosols with nine size bins (cutoff points were $0.43,0.65,1.1,2.1,3.3,4.7,5.8$ and $9.0 \mu \mathrm{m}$, respectively) were collected by using an Anderson sampler at an airflow rate of $28.3 \mathrm{~L} \mathrm{~min}^{-1}$ for $24 \mathrm{~h}$. All samples were collected onto the pre-baked $\left(450^{\circ}\right.$ for $\left.6 \mathrm{~h}\right)$ quartz filters and stored in a freezer $\left(-18^{\circ}\right)$ prior to analysis.

\subsection{Chemical analysis}

A punch $\left(0.526 \mathrm{~cm}^{3}\right)$ from each $\mathrm{PM}_{2.5}$ filter sample was analyzed for organic carbon (OC) and elemental carbon (EC) with a DRI model 2001 thermal-optical carbon analyzer (Atmoslytic Inc., Calabasas, CA, USA) following the IMPROVE-A protocol (Chow et al., 2007). More details of the method including quality assurance and quality control (QA-QC) can be found elsewhere (Wang et al., 2010).

Partial filters were cut into pieces and then extracted three times under sonication with $15 \mathrm{~mL}$ Milli-Q pure water $(18.2 \mathrm{M} \Omega)$. Ten ions such as $\mathrm{SO}_{4}^{2-}, \mathrm{NO}_{3}^{-}, \mathrm{Cl}^{-}, \mathrm{NH}_{4}^{+}$ and $\mathrm{K}^{+}$were determined using ion chromatography (Dionex, ICS-1100). Similar extraction processes were also applied to measure the water-soluble organic carbons (WSOCs) of the samples, which were determined by using a Shimadzu TOC5000 carbon analyzer. The detailed method has been reported by Wang et al. (2013). In order to analyze the organic compounds in the samples such as levoglucosan, PAHs, OPAH and nitrophenols, an aliquot of the filter was extracted with a mixture of methanol and dichloromethane (DCM, 1:5, $v / v$ ), derivatized with bis(trimethylsilyl)trifluoroacetamide (BSTFA, HP 7890A, Agilent Co., USA) coupled with a mass spectrometer (GC-MS) (HP 5975, Agilent Co., USA). Details of sample extraction and derivatization were documented elsewhere (Wang et al., 2009b; Ren et al., 2017). Stable carbon isotope composition of total carbon $\left(\delta^{13} \mathrm{C}_{\mathrm{TC}}\right)$ was determined by using an elemental analyzer (EA) (Carlo Erba, NA 1500) coupled with an isotope ratio mass spectrometer (IRMS, Finnigan MAT DELTA Plus), more details of the method can be found elsewhere (Cao et al., 2016). 


\subsection{Light absorption measurements}

Brown carbon $(\mathrm{BrC})$ was extracted from $6 \mathrm{~cm}^{3}$ filter samples for $30 \mathrm{~min}$ ultrasonication with $20 \mathrm{~mL}$ Milli-Q pure water or methanol. All extracts were then filtered through $0.45 \mu \mathrm{m}$ PTFE (for water) and $0.22 \mu \mathrm{m}$ PES (for methanol) pore syringe filters to remove insoluble components and filter debris. The light absorption spectra were analyzed with a UVvisible spectrophotometer (AOE Instruments, China) over a wavelength range of 190-900 nm (Hecobian et al., 2010). The absorption coefficient of water or methanol extracts (M $\mathrm{m}^{-1}$ ) could be calculated as the following equation (Teich et al., 2017):

$\operatorname{abs}_{\lambda}=\left(A_{\lambda}-A_{700}\right) \frac{V_{1}}{V_{\mathrm{a}} \times L} \times \ln (10)$,

where $A_{\lambda}$ and $A_{700}$ were the light absorption of the extracts at the wavelengths of $\lambda$ and $700 \mathrm{~nm}$, respectively. $V_{1}$ represents the volume of the solvent extracting the filter sample, and $V_{\mathrm{a}}$ refers to the volume of air corresponding to the filter punch. $L$ is the absorbing path length (i.e., $1 \mathrm{~cm}$ for the currently used quartz cuvettes). The $\ln (10)$ is converted from base 10 (the form provided by the spectrophotometer) to natural logarithms. According to previous studies, the absorption coefficient at $365 \mathrm{~nm}$ was used as the brown carbon absorption in order to avoid disturbance of inorganic salts such as nitrate.

The bulk mass absorption coefficient (MAC, $\mathrm{m}^{2} \mathrm{~g}^{-1}$ ) of the extracts at a given wavelength can be described by the following equation:

$\mathrm{MAC}=\frac{\mathrm{abs}_{\lambda}}{C_{\mathrm{W}(\mathrm{M}) \mathrm{SOC}}}$,

where $C_{\mathrm{W}(\mathrm{M}) \mathrm{SOC}}$ is the atmospheric concentration of the particulate water-soluble organic carbon (WSOC) or methanolsoluble organic carbon (MSOC, $\mu \mathrm{gC} \mathrm{m}^{-3}$ ). In this study, we assumed that $\mathrm{OC}$ could be completely dissolved in methanol solvent and substituted the MSOC for the calculation. This hypothesis would possibly lead to somewhat underestimation of the MAC of the methanol extracts, although high extraction efficiency of methanol solvent had been reported by previous studies (Liu et al., 2013).

The wavelength dependence of light absorption with respect to the empirically defined power-law relationship is described by the following equation (Laskin et al., 2015):

$\mathrm{MAC}=K \lambda^{-\mathrm{AAE}}$,

where $K$ is a factor that includes aerosol mass concentrations, and AAE denotes the absorption Ångström exponent. In this study, the AAE value of the filter extracts was determined by a $\operatorname{linear}$ regression of $\log (\operatorname{abs} \lambda)$ versus $\log (\lambda)$ over a wavelength range of $300-450 \mathrm{~nm}$.

\subsection{Positive matrix factorization (PMF) source apportionment}

PMF, as a receptor model, decomposes the sample matrix into two matrices (factor contributions and factor profiles) and has been widely used for the source apportionment of atmospheric pollutants. More details on PMF can be found on the EPA website (https://www.epa.gov/airresearch/epa-positive-matrix-factorization-50-fundamentalsand-user-guide, last access: 16 May 2019). In the present work, the mass concentrations of major species (OC, EC, WSOC, $\mathrm{SO}_{4}^{2-}, \mathrm{NO}_{3}^{-}, \mathrm{NH}_{4}^{+}$and $\left.\mathrm{Ca}^{2+}\right)$, organic markers (benzo(b)fluoranthene $(\mathrm{BbF})$, benzo(e)pyrene $(\mathrm{BeP})$, indeno(1,2,3-c,d)pyene (IP), levoglucosan and nitrophenols) and $\operatorname{abs}_{\lambda}$ of water extracts have been used as the input data to perform the source apportionment for brown carbon with the EPA PMF 5.0 version; similar reports have been found elsewhere (Hecobian et al., 2010). The model was run numerous times with three to seven factors and various combinations of the concentration and absorption data set. Based on the $Q$ value ( $Q_{\text {true }}$ and $Q_{\text {robust }}$ ) and $r$, which are indicative of the agreement of the model fit, four factors were obtained as the optimal solution.

\section{Results and discussion}

\subsection{Carbonaceous species in $\mathbf{P M}_{2.5}$ during summer and winter}

Figure 1 shows the temporal variations in the concentrations of $\mathrm{PM}_{2.5}$, WSOC, OC and $\mathrm{abs}_{\lambda=365 \mathrm{~nm}}$ values during the two seasons. WSOC varied from 5.3 to $67 \mu \mathrm{gC} \mathrm{m}{ }^{-3}$ in winter with an average of $23 \pm 13 \mu \mathrm{gC} \mathrm{m}{ }^{-3}$ (Table 1), which was 4.0 times higher than that in summer. OC exhibited a seasonal variation similar to that of WSOC with an average of $41 \pm 25 \mu \mathrm{gC} \mathrm{m}^{-3}$ in winter and $8.4 \pm 2.4 \mu \mathrm{gC} \mathrm{m}^{-3}$ in summer, respectively. However, WSOC/OC ratio was much higher in summer $(0.70 \pm 0.12)$ than that in winter $(0.58 \pm 0.13)$, partly as a result of an enhanced photochemical formation of WSOC under the intense sunlight conditions. Similar phenomena were also found in Beijing (Ping et al., 2017), Shanghai (Zhao et al., 2015a), Tokyo (Miyazaki et al., 2006) and the southeastern US (Ding et al., 2008).

PAHs, OPAHs and nitrophenols are ubiquitous in the atmosphere and can be directly emitted from incomplete combustion of carbon-containing fuels (e.g., coal, biomass) (Shen et al., 2013; Zhang and Tao, 2009). In addition, OPAHs and nitrophenols can also be produced from photochemical reactions (Cochran et al., 2016; Keyte et al., 2013; Yuan et al., 2016). These compounds are the efficient light-absorbing species, because their molecular structures consist of chromophores (Lin et al., 2017; Bluvshtein et al., 2017). Herein, 14 PAHs, 7 OPAHs and 7 nitrophenols were examined for investigating their effect on $\mathrm{BrC}$ absorption. As seen in Fig. S1, 

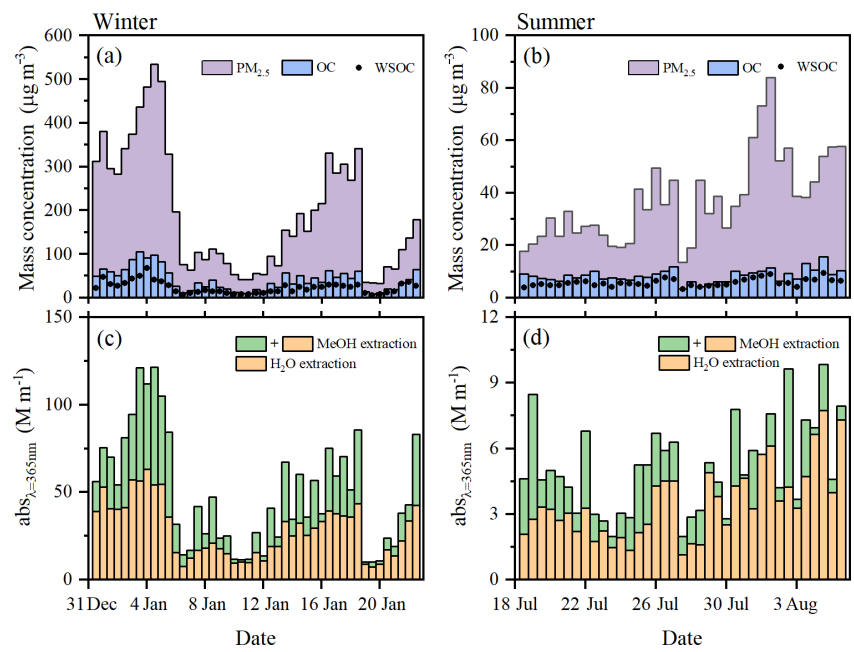

Figure 1. Temporal variations in WSOC, OC, $\mathrm{PM}_{2.5}$ and $\operatorname{abs}_{\lambda=365} \mathrm{~nm}$ of $\mathrm{PM}_{2.5}$ samples extracted by water $\left(\mathrm{H}_{2} \mathrm{O}\right.$ extraction $)$ and methanol ( $\mathrm{MeOH}$ extraction) during winter (a, c) and summer (b, d).

Table 1. Concentrations of organic carbon in $\mathrm{PM}_{2.5}$ and meteorological conditions during winter and summer of 2017 in Xi' an, inland China.

\begin{tabular}{|c|c|c|}
\hline & Winter & Summer \\
\hline \multicolumn{3}{|c|}{ (i) Mass concentrations of organic matter in $\mathrm{PM}_{2.5}$} \\
\hline WSOC $\left(\mu \mathrm{gC} \mathrm{m}{ }^{-3}\right)$ & $23 \pm 13$ & $5.8 \pm 1.4$ \\
\hline $\mathrm{OC}\left(\mu \mathrm{gCm} \mathrm{m}^{-3}\right)$ & $41 \pm 25$ & $8.4 \pm 2.4$ \\
\hline PAHs $\left(\mathrm{ng} \mathrm{m}^{-3}\right)$ & $149 \pm 89$ & $8.1 \pm 6.5$ \\
\hline OPAHs $\left(\mathrm{ng} \mathrm{m}^{3}\right)$ & $174 \pm 98$ & $17 \pm 8.7$ \\
\hline Nitrophenols $\left(\mathrm{ng} \mathrm{m}^{3}\right)$ & $17 \pm 12$ & $0.40 \pm 0.27$ \\
\hline Levoglucosan $\left(\mathrm{ng} \mathrm{m}^{-3}\right)$ & $739 \pm 432$ & $29 \pm 22$ \\
\hline \multicolumn{3}{|c|}{ (ii) $\mathrm{PM}_{2.5}$ and meteorological parameters } \\
\hline $\mathrm{PM}_{2.5}\left(\mu \mathrm{g} \mathrm{m}^{-3}\right)$ & $194 \pm 141$ & $37 \pm 16$ \\
\hline$T\left({ }^{\circ}\right)$ & $2.6 \pm 2.9$ & $31 \pm 5.4$ \\
\hline $\mathrm{RH}(\%)$ & $60 \pm 20$ & $58 \pm 19$ \\
\hline Visibility (km) & $7.0 \pm 7.0$ & $21 \pm 11$ \\
\hline
\end{tabular}

the temporal variations in PAHs, OPAHs and nitrophenols were similar to levoglucosan, which is the tracer of biomass burning emissions, indicating that biomass burning is one of the major sources of these compounds. Concentrations of PAHs, OPAHs and nitrophenols during winter were $149 \pm 89$, $174 \pm 98$ and $17 \pm 12 \mathrm{ng} \mathrm{m}^{-3}$ (Table 1), respectively, and were 10-43 times higher than those in summer, which can be explained by increasing emissions from residential heating during winter in the city and its surrounding regions.

As shown in Supplement Table $S 1$, $\operatorname{abs}_{\lambda}=365 \mathrm{~nm}$ extracted by methanol displays good correlations with PAHs, OPAHs and nitrophenols, especially in winter $(r>0.89)$, which suggests that those species are important light absorption con- tributors for $\mathrm{BrC}$ in $\mathrm{Xi}$ 'an. Huang et al. (2018) found that PAHs and OPAHs in Xi' an accounted for, on average, $1.7 \%$ of the overall absorption of methanol-soluble $\mathrm{BrC}$, but their mass fraction in OC was only $0.35 \%$. A recent study reported that biomass burning also emitted nitroaromatic compounds, particularly nitrophenols, and accounted for $50 \%-80 \%$ of the total visible light absorption (>400 nm) (Lin et al., 2017). The robust correlations of the above compounds with the absorption at $\lambda=365 \mathrm{~nm}$ suggest that PAHs, OPAHs and nitrophenol are strong light-absorbing species.

\subsection{Light absorption of $\mathrm{BrC}$ in water and methanol extracts}

\subsubsection{Seasonal variations in light absorption by $\mathrm{BrC}$}

As shown in Fig. 2a and b, the marked feature of $\mathrm{BrC}$ in $\mathrm{Xi}$ 'an is that the absorption spectrum increased notably from the visible to the ultraviolet ranges, and the average abs$\mathrm{MeOH}$ at $\lambda=365 \mathrm{~nm}$ was $1.5-1.7$ times higher than abs$\mathrm{H}_{2} \mathrm{O}$ in the two seasons, indicating that MSOC provided a more comprehensive estimation for $\mathrm{BrC}$. Due to enhanced emission of $\mathrm{BrC}$, average $\mathrm{abs}_{\lambda}=365 \mathrm{~nm}$ of $\mathrm{BrC}$ found in winter was $49 \pm 32 \mathrm{M} \mathrm{m}^{-1}$ for $\mathrm{MeOH}$ extracts and $28 \pm 16 \mathrm{M} \mathrm{m}^{-1}$ for WSOC, which were 9.5- and 8.1-fold higher than that in summer. This phenomenon was also observed in previous studies in Xi' an (Shen et al., 2017; Huang et al., 2018) and other areas of China (Du et al., 2014; Chen et al., 2018). Compared with other regions (Table 2), the absolute $\operatorname{abs}_{\lambda}=365 \mathrm{~nm}$ values in Xi' an were slightly lower than those in the Indo-Gangetic Plain, India (Satish et al., 2017; Bachi, 2016), but were considerably higher than those in Beijing, China (Du et al., 2014); the US (Zhang et al., 2011); and South Korea (Kim et al., 2016), suggesting heavy pollution of light-absorbing aerosols in Xi'an. Furthermore, enhanced $\operatorname{abs} \lambda=365 \mathrm{~nm}$ loading in the nighttime was observed during the two seasons, which can be ascribed to the shallower boundary layer height and the absence of photo-bleaching processes at night (Saleh et al., 2013; Zhao et al., 2015b).

Linear regression slopes in the scatter plots of $\mathrm{abs}_{\lambda}=365 \mathrm{~nm}$ values versus WSOC or MSOC represent the average of $\mathrm{MAC}$ at $365 \mathrm{~nm}$ (i.e., $\mathrm{MAC}_{\mathrm{WSOC}}$ and $\mathrm{MAC}_{\mathrm{MSOC}}$ ). During winter, there was a slight disparity between the MAC $\mathrm{WSOC}_{\mathrm{W}}$ and $\mathrm{MAC}_{\mathrm{MSOC}}$ with the averages of $1.2 \pm 0.06$ and $1.3 \pm$ $0.03 \mathrm{~m}^{2} \mathrm{~g}^{-1}$ (Fig. 2e), respectively, which indicates that there are some similar chromophores of $\mathrm{BrC}$ between the two fractions. As seen in Table 2, both $\mathrm{MAC}_{\mathrm{WSOC}}$ and $\mathrm{MAC}_{\mathrm{MSOC}}$ in Xi'an during the two seasons are higher than those in the US and Korea, suggesting that $\mathrm{BrC}$ in the city was comprised of stronger light-absorbing compounds. $\operatorname{abs}_{\lambda=365 \mathrm{~nm}}$ showed a strong linear correlation with levoglucosan $(r>0.98)$, suggesting that abundant $\mathrm{BrC}$ was largely derived from biomass burning. As shown in Fig. S2, mass ratios of levoglucosan/mannosan and levoglucosan/galacosan in the $\mathrm{PM}_{2.5}$ samples are similar to biomass types (i.e., 

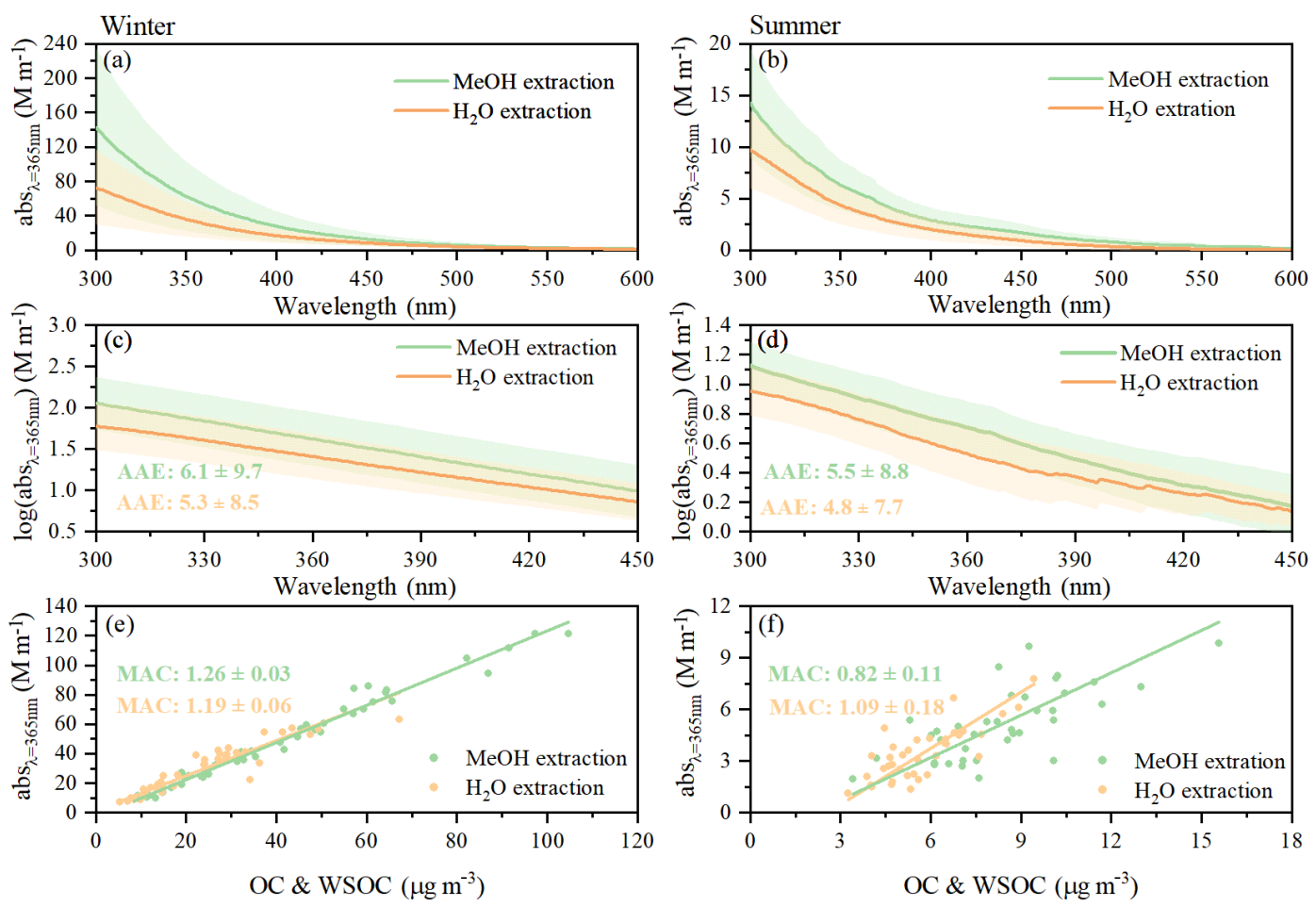

Figure 2. Seasonal average values of $\mathrm{abs}_{\lambda=365 \mathrm{~nm}}$, AAE and MAC extracted by $\mathrm{MeOH}$ and $\mathrm{H}_{2} \mathrm{O}$. AAE is calculated by a linear regression fit $\log \left(\operatorname{abs}_{\lambda=365 \mathrm{~nm}}\right)$ versus $\log (\lambda)$ in the wavelength range of $300-450 \mathrm{~nm}$. The shading indicates the standard deviations.

Table 2. Comparison of light absorption $\left(\mathrm{abs}_{\lambda=365 \mathrm{~nm}}\right)$, MAC and AAE values of water extracts of PM 2.5 in Xi'an, China, with those in other cities.

\begin{tabular}{|c|c|c|c|c|c|c|c|c|}
\hline \multirow[t]{2}{*}{ Location } & \multirow[t]{2}{*}{ Time } & \multicolumn{2}{|c|}{$\operatorname{abs}_{\lambda=365 \mathrm{~nm}}\left(\mathrm{Mm}^{-1}\right)$} & \multicolumn{2}{|c|}{ MAC $\left(\mathrm{m}^{2} \mathrm{~g}^{-1}\right)$} & \multicolumn{2}{|c|}{$\mathrm{AAE}$} & \multirow[t]{2}{*}{ References } \\
\hline & & Winter & Summer & Winter & Summer & Winter & Summer & \\
\hline \multirow[t]{2}{*}{ Xi'an, China } & 2016-2017 & $49 \pm 32^{\mathrm{a}}$ & $5.2 \pm 2.1^{\mathrm{a}}$ & $1.3 \pm 0.03^{\mathrm{a}}$ & $0.8^{\mathrm{a}} \pm 0.1^{\mathrm{a}}$ & $6.1 \pm 9.7^{\mathrm{a}}$ & $5.5 \pm 8.8^{\mathrm{a}}$ & This study \\
\hline & 2008-2009 & $\begin{array}{r}28 \pm 16 \\
46 \pm 20^{\mathrm{a}} \\
25 \pm 12\end{array}$ & $\begin{array}{r}3.5 \pm 1.7 \\
8.3 \pm 2.3^{\mathrm{a}} \\
5.0 \pm 1.3\end{array}$ & $\begin{array}{r}1.2 \pm 0.06 \\
1.3^{\mathrm{a}} \\
1.7\end{array}$ & $\begin{array}{r}1.1 \pm 0.2 \\
0.7^{\mathrm{a}} \\
1.0\end{array}$ & $\begin{array}{r}5.3 \pm 8.5 \\
6.0^{\mathrm{a}} \\
5.7\end{array}$ & $\begin{array}{r}4.8 \pm 7.7 \\
6.0^{\mathrm{a}} \\
5.7\end{array}$ & Huang et al. (2018) \\
\hline Beijing, China & $\begin{array}{l}2010-2011 \\
2011 \\
2013\end{array}$ & $\begin{array}{l}10 \pm 8.6 \\
10 \pm 6.9 \\
14 \pm 5.2\end{array}$ & $\begin{array}{l}3.7 \pm 3.8 \\
4.6 \pm 2.2\end{array}$ & $\begin{array}{l}1.3 \\
1.2 \\
1.5\end{array}$ & 0.7 & $\begin{array}{l}7.3 \\
5.3\end{array}$ & 5.8 & $\begin{array}{l}\text { Du et al. (2014) } \\
\text { Cheng et al. (2016) } \\
\text { Yan et al. (2015) }\end{array}$ \\
\hline Nanjing, China & 2015-2016 & $9.4 \pm 4.7$ & $3.3 \pm 2.4$ & 1.0 & 0.5 & 6.7 & 7.3 & Chen et al. (2018) \\
\hline Guangzhou, China & 2012 & $3.6 \pm 1.3$ & & 0.8 & & 5.3 & & Liu et al. (2018) \\
\hline Delhi, India & $2010-2011$ & & & 1.6 & & 5.1 & & Kirillova et al. (2014) \\
\hline Indo-Gangetic Plain, India & $\begin{array}{l}2015-2016 \\
2011\end{array}$ & $\begin{array}{r}24 \pm 19 \\
40 \pm 18^{b} \\
52 \pm 27^{c}\end{array}$ & & $\begin{array}{l}1.2 \\
1.3^{\mathrm{b}} \\
1.3^{\mathrm{c}}\end{array}$ & & $\begin{array}{l}5.1^{\mathrm{b}} \\
5.3^{\mathrm{c}}\end{array}$ & & $\begin{array}{l}\text { Satish et al. (2017) } \\
\text { Bachi et al. (2016) }\end{array}$ \\
\hline Seoul, South Korea & 2013-2013 & $\begin{array}{l}11^{\mathrm{a}} \\
7.3\end{array}$ & $\begin{array}{r}5.8^{\mathrm{a}} \\
0.9\end{array}$ & $\begin{array}{r}0.9^{\mathrm{a}} \\
1.0\end{array}$ & $\begin{array}{r}1.5^{\mathrm{a}} \\
0.3\end{array}$ & $\begin{array}{r}5.5^{\mathrm{a}} \\
5.8\end{array}$ & $\begin{array}{r}4.1^{\mathrm{a}} \\
8.7\end{array}$ & Kim et al. (2016) \\
\hline Atlanta, US & 2010 & & $0.6 \pm 0.4$ & & $1.2-0.2$ & & 3.4 & Zhang et al. (2011) \\
\hline Los Angeles Basin, US & 2010 & & $0.4-1.6$ & & 0.7 & & 7.6 & Zhang et al. (2013) \\
\hline
\end{tabular}

${ }^{a}$ Solution extracted by MeOH. ${ }^{b}$ Samples collected in daytime. ${ }^{c}$ Samples collected in the night. 
woods, leaves, wheat straw), again reflecting that biomass burning combustion in $\mathrm{Xi}$ ' an and its surrounding regions is probably the major source of $\mathrm{BrC}$ in the city during winter. Compared to winter, the MAC in summer was slightly lower, which can be in part attributed to the less abundant light-absorbing PAHs and OPAHs due to no biomass burning for house heating. Moreover, with increasing photooxidation in summer, fragmentation reactions would occur and thus decrease light absorption for $\mathrm{BrC}$ aerosols, as reported by Sumlin et al. (2017), because higher levels of $\mathrm{O}_{3}$ and $\mathrm{OH}$ radicals in summer intensify the photooxidation and diminish the $\mathrm{BrC}$ aerosol light absorption by reducing the size of conjugated molecular systems. Interestingly, we found that the $\operatorname{MAC}_{\text {WSOC }}\left(1.1 \pm 0.2 \mathrm{~m}^{2} \mathrm{~g}^{-1}\right)$ in summer was significantly enhanced compared to MAC $\operatorname{MSOC}_{2}\left(0.8 \pm 0.1 \mathrm{~m}^{2} \mathrm{~g}^{-1}\right)$, which can be ascribed to more non-BrC in the methanol extracts such as phthalates, of which the abundance relative to $\mathrm{OC}$ was about 10 times higher in summer than in winter. The $a s_{\lambda}=365 \mathrm{~nm}$ showed a poor correlation with levoglucosan (Table S1), further indicating that the biomass burning was not the dominant source for $\mathrm{BrC}$ in summer.

Absorption Ångström exponents (AAEs), which were derived from the filter methanol- and water-extracted $\mathrm{BrC}$ ( $\mathrm{AAE}_{\mathrm{WSOC}}$ and $\mathrm{AAE}_{\mathrm{MSOC}}$ ) for wavelengths between 300 and $450 \mathrm{~nm}$, were $6.1 \pm 9.7$ and $5.3 \pm 8.5$ (Table 2) in winter, respectively, and resembled that in Beijing (Cheng et al., 2016), Guangzhou (Liu et al., 2018) and the Indo-Gangetic Plain (Bachi, 2016), possibly indicating that the chemical compositions of $\mathrm{BrC}$ chromophores in these regions are similar during winter. As seen in Table 2, unlike those of $\mathrm{H}_{2} \mathrm{O}$ extracts, the averaged values of MAC and AAE of $\mathrm{MeOH}$ extracts were $40 \%$ and $10 \%$ higher in winter than in summer, respectively, suggesting that chemical compositions of $\mathrm{BrC}$ are different between the two seasons in the city and the winter $\mathrm{BrC}$ contained more nonpolar compounds that are of stronger light-absorbing ability.

\subsubsection{Aerosol size distribution of $\mathrm{BrC}$}

Particles with different sizes are of different chemical compositions, and thus optical properties of $\mathrm{BrC}$ in different sizes of particles are also different (Zhang et al., 2015; Zhai et al., 2017). However, information on size distribution of $\mathrm{BrC}$ absorption is very limited. In this study, we mainly focused on the water-extracted samples, because particles deposited on the filter surface are unevenly distributed, making the quantifications of OC and EC in the size-segregated samples not accurate enough. As shown in Fig. S3, there was a good relationship between the $a s_{\lambda}=365 \mathrm{~nm}(r>0.98)$ of the samples collected by the Anderson sampler and those collected by the high-volume $\mathrm{PM}_{2.5}$ sampler (Fig. S3), suggesting a good agreement between the two sampling methods.

As shown in Fig. 3, abs $\lambda=365 \mathrm{~nm}$ presented a bimodal pattern during winter and summer, dominating in the fine mode $\left(D_{\mathrm{p}}<2.1 \mu \mathrm{m}\right)$ with relative contributions of $81 \%$ and $65 \%$ to
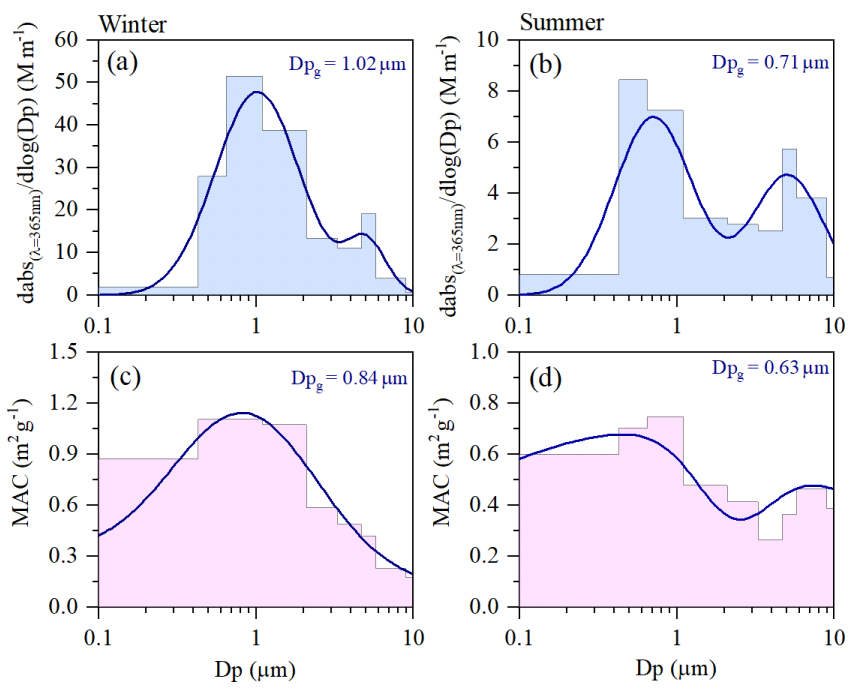

Figure 3. Size distributions of $\mathrm{abs}_{\lambda=365 \mathrm{~nm}}$ and $\mathrm{MAC}$ of $\mathrm{PM}_{2.5}$ samples extracted by water during the winter and summer of 2017 in Xi' an. Dpg is the geometric mean diameter of particles.

the total absorption in the two seasons, respectively. These proportions are similar to those reported for a forest wildfire event, which showed that $93 \%$ of the total BrC absorption was in the fine particles $\left(0.10<D_{\mathrm{p}}<1.0 \mu \mathrm{m}\right)$ (Lorenzo et al., 2018). Maximum absorptions were observed at 1.02 and $0.71 \mu \mathrm{m}$ (Fig. $3 \mathrm{a}$ and $\mathrm{b}$ ) in winter and summer, respectively, which is in agreement with the observations by Lei et al. (2018), who found that the major peaks for BrC absorption were in the range from 0.5 to $1.0 \mu \mathrm{m}$ in urban emissions and may shift toward a smaller size $(<0.4 \mu \mathrm{m})$ for particles released from burning experiments (Lei et al., 2018). However, the size distribution pattern of MAC was different from that of $\operatorname{abs}_{\lambda=365 \mathrm{~nm}}$ in Xi'an, which presented a monomodal distribution with a peak in the fine mode $(<2.1 \mu \mathrm{m})$ in winter and a bimodal distribution in summer with two peaks in the fine $(<2.1 \mu \mathrm{m})$ and coarse $(>2.1 \mu \mathrm{m})$ modes (Fig. $3 \mathrm{c}$ and d). As seen in Fig. $3 \mathrm{c}$ and d, the fine mode of MAC was around $50 \%$ larger in winter than that in summer, suggesting that the water-soluble fraction of winter fine particles was more light-absorbing compared to that in summer, probably due to the stronger summertime bleaching effect.

\subsection{Underestimation of $\mathrm{BrC}$ absorption by solvent extraction methods}

A few studies pointed out that absorption properties of $\mathrm{BrC}$ extracted by bulk solution may not entirely reflect the light absorption by ambient aerosols. Here, we further calculated the light absorption of the samples using the Mie theory combined with an imaginary ( $k$, responsible for absorption) refractive index with assumptions that particles were of spherical morphology and externally mixed with other lightabsorbing components. The imaginary refractive index could 
Table 3. Complex refractive index $(k)$ of brown carbon from samples extracted by water in two seasons.

\begin{tabular}{lrc}
\hline $\begin{array}{l}\text { Particle size } \\
(\mu \mathrm{m})\end{array}$ & Winter & Summer \\
\hline 1.31 & $0.047 \pm 0.005$ & $0.021 \pm 0.010$ \\
0.73 & $0.048 \pm 0.008$ & $0.033 \pm 0.010$ \\
0.45 & $0.048 \pm 0.013$ & $0.031 \pm 0.009$ \\
0.18 & $0.038 \pm 0.016$ & $0.026 \pm 0.008$ \\
\hline
\end{tabular}

be obtained from MAC using the following equation (Laskin et al., 2015):

$k_{(\lambda)}=\frac{\rho \lambda \mathrm{abs}}{4 \pi \times \mathrm{WSOC}}=\frac{\rho \lambda \mathrm{MAC}}{4 \pi}$,

where $\rho\left(\mathrm{g} \mathrm{cm}^{-3}\right)$ was particle density and assigned as 1.5 ; more details about Mie calculations can be found in the study by Liu et al. (2013).

As noted above, most $\mathrm{BrC}$ aerosols were in the fine mode $(<2.1 \mu \mathrm{m})$; thus, here we only focused on this fraction for the Mie calculations. The values of imaginary refractive index in winter remain nearly constant $(0.038-0.048)$ for different particle sizes at $\lambda=365 \mathrm{~nm}$ (Table 3 ), which was about 2 times smaller than that $(0.093 \pm 0.049)$ over the Gangetic Plain, India (Shamjad et al., 2017). Values of $k$ in summer were slightly smaller when compared to those in winter, suggesting that the aerosols in summer were more aged. Sumlin et al. (2017) found that $k$ decreases along with the atmospheric aging from $0.029 \pm 0.001$ to $0.019 \pm 0.001$ at $\lambda=$ $375 \mathrm{~nm}$. However, $k$ values in this study were 5.0 times (avg.) higher than those reported from the US (Liu et al., 2013). This is because $\mathrm{PM}_{2.5}$ particles in Xi' an, China, are enriched in $\mathrm{BrC}$ and the mass absorption coefficient was considerably higher than that in the US. Figure 4 compares the difference between $\mathrm{abs}_{\lambda=365 \mathrm{~nm}}$ predicted by Mie theory (abs-Mie) and that extracted by the bulk solution (abs-Measure). Mie theory predicted $a b s_{\lambda=365 \mathrm{~nm}}$ that was 1.5 -fold higher than that measured by the bulk solution, suggesting that the solvent extraction methods, which have commonly been used for atmospheric $\mathrm{BrC}$ measurements, could result in an underestimation of optical absorption of aerosols. Hence, a factor of 1.5 is recommended to convert the liquid-based data (at least for the water-soluble data) reported by this work for estimating optical properties of atmospheric aerosols in Xi' an and its surrounding regions in order to better quantify the $\mathrm{BrC}$ light absorption.

\subsection{The characteristics of $\mathrm{BrC}$ with aerosol aging}

During the aging process, secondary organic aerosols (SOAs) with strong chromophores can be generated and efficiently absorb solar radiation (Lin et al., 2014, 2016). From Fig. 5, it can be found that air quality in Xi' an during the winter varied from clean $\left(\mathrm{PM}_{2.5}<75 \mu \mathrm{g} \mathrm{m}^{-3}\right)$ to polluted conditions

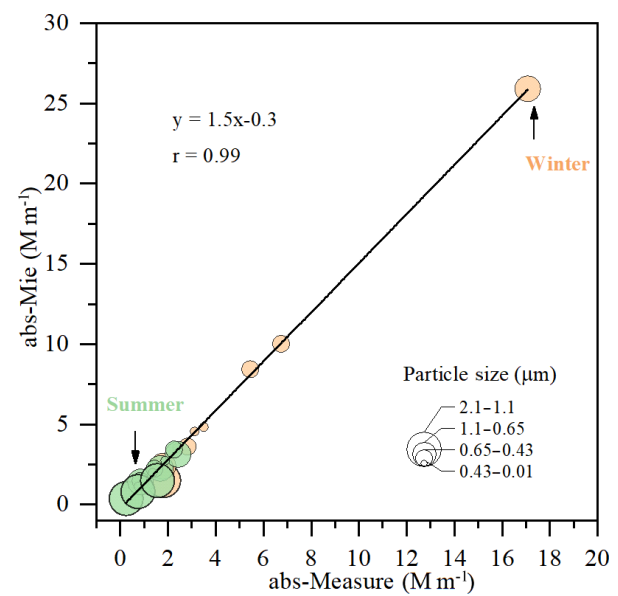

Figure 4. An orthogonal regression analysis for $\mathrm{abs}_{\lambda}=365 \mathrm{~nm}$ between samples predicted by Mie theory and extracted by water for different particle sizes $\left(D_{\mathrm{p}}<2.1 \mu \mathrm{m}\right)$.

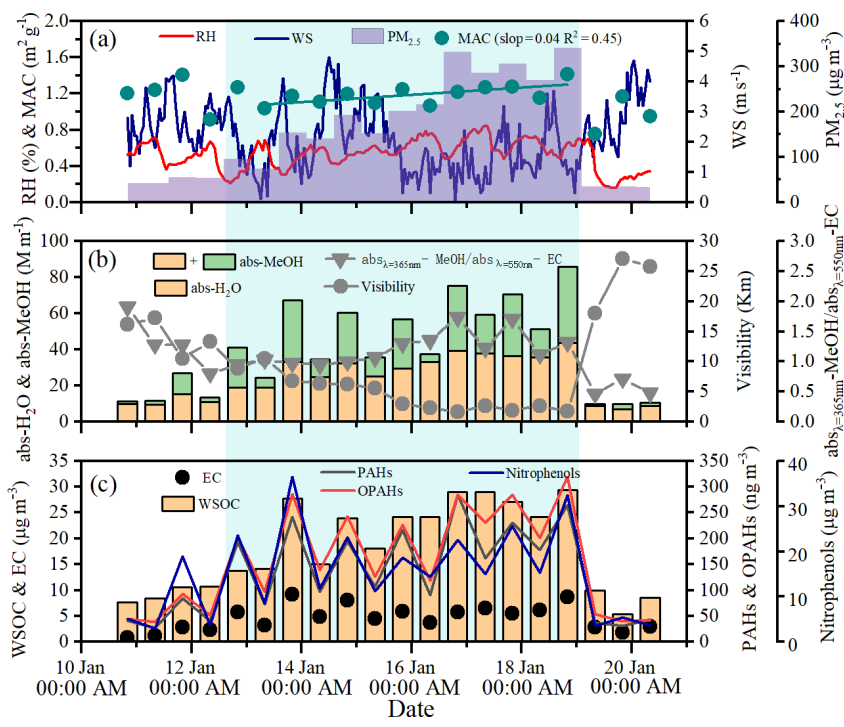

Figure 5. Temporal variations in $\mathrm{PM}_{2.5}$, meteorological parameters, $a_{\lambda s_{\lambda}=365 \mathrm{~nm}}$ of $\mathrm{W}(\mathrm{M}) \mathrm{SOC}$ and organic compounds in the period of 10-20 January. The cyan shadow indicates a haze period from 12 to 19 January 2017 with a daily $\mathrm{PM}_{2.5}>75 \mu \mathrm{g} \mathrm{m}^{-3}$.

$\left(\mathrm{PM}_{2.5}>75 \mu \mathrm{g} \mathrm{m}^{-3}\right)$ from the period of 12 January to $19 \mathrm{Jan}-$ uary. Such a case provides an opportunity to investigate the changes in light absorption by $\mathrm{BrC}$ during the aerosol aging process.

As shown in Fig. 5a and b, abs $\lambda=365 \mathrm{~nm}$ extracted by water and $\mathrm{MeOH}$ in $\mathrm{Xi}$ ' an during the campaign showed an increasing trend from 12 to 19 January, which is similar to $\mathrm{PM}_{2.5}$ loadings but opposite to the visibility, indicating that $\mathrm{BrC}$ is one of the important factors leading to visibility deterioration. From Fig. 5b, it can also be seen that light absorption of water extracts dominated over the total $\mathrm{BrC}$ absorption, especially in daytime and showed a variation pattern similar to 
the $\mathrm{PM}_{2.5}$ (Fig. 5a) and WSOC loadings (Fig. 5c), indicating a continuous formation of secondary $\mathrm{BrC}$ during the aerosol aging process. To illustrate this point, the stable carbon isotopic composition $\left(\delta^{13} \mathrm{C}_{\mathrm{TC}}\right)$ of total carbon (TC) in the samples was measured. WSOC/OC showed a positive correlation with the $\delta^{13} \mathrm{C}_{\mathrm{TC}}$, demonstrating an aging process of aerosols during the haze development from 12 to 19 January, although it was weak $(r=0.47, n=17)$. Similar conclusions were also reported by Yang et al. (2004) and Pavuluri et al. (2015). From Fig. 5c, increasing trends of OPAHs and nitrophenols were observed during the haze development, suggesting that more SOAs with chromophores were generated during such an aerosol aging process, because these compounds are also of secondary origin. To exclude the possible impact of the changes in $\mathrm{BrC}$ source emissions, the values of PAHs/OC and levoglucosan/OC were applied in this study, because PAHs and levoglucosan emission factors are different for different sources (Nguyen-Duy and Chang, 2017). As shown in Fig. S4, both values indistinctively changed during the aerosol aging process, indicating that the increasing $a b s_{\lambda}=365 \mathrm{~nm}$ values were not caused by the changes in source emissions. Moreover, we found that $\mathrm{MAC}_{\mathrm{MSOC}}$ values during the age process also increased (Fig. 5a), further suggesting that the bleaching effect on light-absorbing $\mathrm{BrC}$ was reducing during the haze developing process.

$\mathrm{EC}$ is one of the major light-absorbing aerosols in the atmosphere (Collier et al., 2018; Peng et al., 2016). To further discuss the changes of $\mathrm{BrC}$ during the aerosol aging process, we compared the mass absorption efficiency of $\mathrm{EC}$ at $\lambda=550 \mathrm{~nm}\left(7.5 \pm 1.2 \mathrm{~m}^{2} \mathrm{~g}^{-1}\right)$ with $\mathrm{BrC}$ by using the method reported from Yan et al. (2015) and Kirillova et al. (2014). As shown in Fig. 5c, the concentrations of EC have a slight change in the haze period, so the changes in light absorption of EC remained nearly constant. However, the ratio of $\mathrm{abs}_{\lambda=365 \mathrm{~nm}}-\mathrm{MeOH} / \mathrm{abs}_{\lambda}=550 \mathrm{~nm}$-EC increasingly became larger along with the visibility deterioration from 12 to 19 January (Fig. 5b), while the mass ratios of PAHs / EC, OPAHs / EC and nitrophenols / EC during the period showed a significant negative correlation with visibility (Fig. S5), further suggesting that the impairment of the visibility from $\mathrm{BrC}$ was getting more significant during the haze development process.

During the haze development process, organic aerosols usually become more aged and enriched in heavier ${ }^{13} \mathrm{C}$ due to the kinetic isotopic effect (KIE) (Wang et al., 2010). As shown in Fig. 6a and b, $\delta^{13} \mathrm{C}$ of $\mathrm{PM}_{2.5}$ samples presented a strong positive correlation with $\operatorname{abs}_{\lambda}=365 \mathrm{~nm}-\mathrm{MeOH}(r=$ 0.82 ) in the daytime, while there was no such correlation in the nighttime during the haze period of 12-19 January, indicating a daytime formation of secondary BrC. From Fig. $6 \mathrm{c}$ and $\mathrm{d}$, we also found that the correlation of $\mathrm{abs}_{\lambda}=365 \mathrm{~nm}^{-}$ $\mathrm{MeOH} / \mathrm{abs}_{\lambda}=550 \mathrm{~nm}$-EC ratio with nitrophenol was much stronger in daytime than in nighttime, which is opposite to the correlation of $\mathrm{abs}_{\lambda=365 \mathrm{~nm}}-\mathrm{MeOH} / \mathrm{abs}_{\lambda}=550 \mathrm{~nm}$-EC ratio with PAHs. Nitrophenols can be produced from secondary
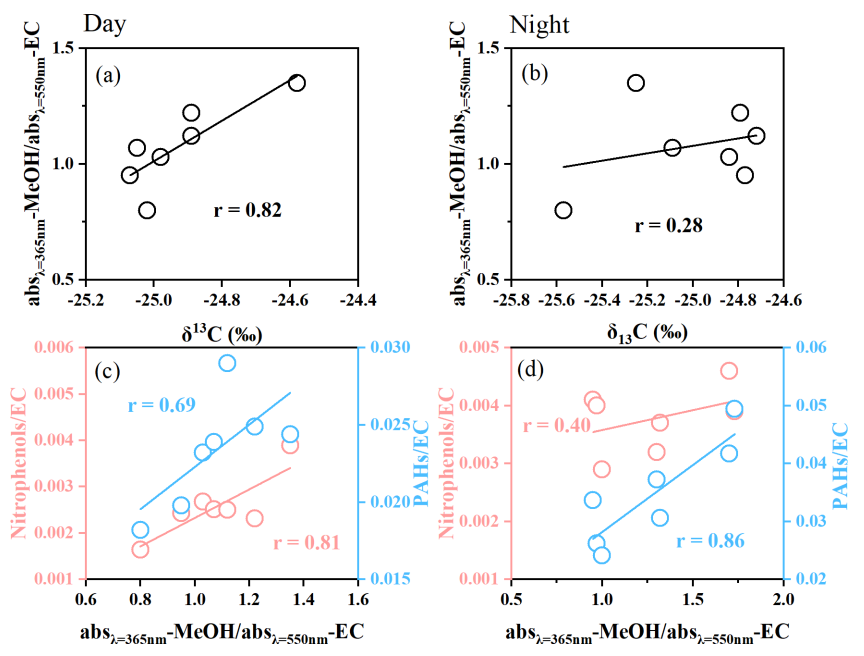

Figure 6. Linear fit regressions for the ratio of light absorption of methanol extracts to light absorption of EC $\left(\mathrm{abs}_{\lambda}=365 \mathrm{~nm}^{-}\right.$

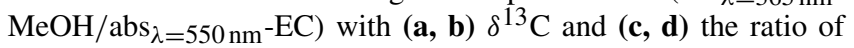
relative abundance of nitrophenol to $\mathrm{EC}$ (nitrophenol / EC) in the daytime and nighttime $\mathrm{PM}_{2.5}$ samples collected during the haze period of 12 to 19 January (corresponding to the cyan shadow in Fig. 5) in Xi'an.

photooxidation of phenol with $\mathrm{NO}_{x}$, while PAHs are produced solely from direct emissions, especially from coal and biomass burning for house heating. The opposite diurnal correlations of the $\mathrm{abs}_{\lambda}=365 \mathrm{~nm}-\mathrm{MeOH} / \mathrm{abs}_{\lambda}=550 \mathrm{~nm}-\mathrm{EC}$ ratio with nitrophenols and PAHs again revealed an enhanced formation of secondary $\mathrm{BrC}$ during the aerosol aging process.

\subsection{Positive matrix factorization (PMF) analysis for BrC source apportionment}

In the current work, the EPA PMF 5.0 model was used for identifying the possible sources of $\mathrm{BrC}$. Because the number of the collected samples in each season was not large enough, data from the two seasons were merged together to form a data set of $80 \times 12$ ( 80 samples with 12 species) in order to obtain an accurate analysis according to the PMF user guide. The resolved source profiles (factors) represented the sources that influenced variability in the selected components throughout two seasons in Xi' an. A similar approach was also reported by Zhang et al. (2010). With several iterative tests, a solution with four factors was identified as the optimal solution. As shown in Table S2, the values of $Q_{\text {true }}$ and $Q_{\text {robust }}$ were consistent, which indicates that the model fits the input data well. Furthermore, the correlation coefficient between input and model values ranged from 0.82 to 0.99 with an average of 0.96 , also implying that the model fit well. This assessment method was widely used in previous studies (Ren et al., 2017; Wang et al., 2009a).

Figure 7 shows the factor profiles resolved by the model. Factor 01 was characterized by high levels of $\mathrm{BeF}(52 \%)$, 


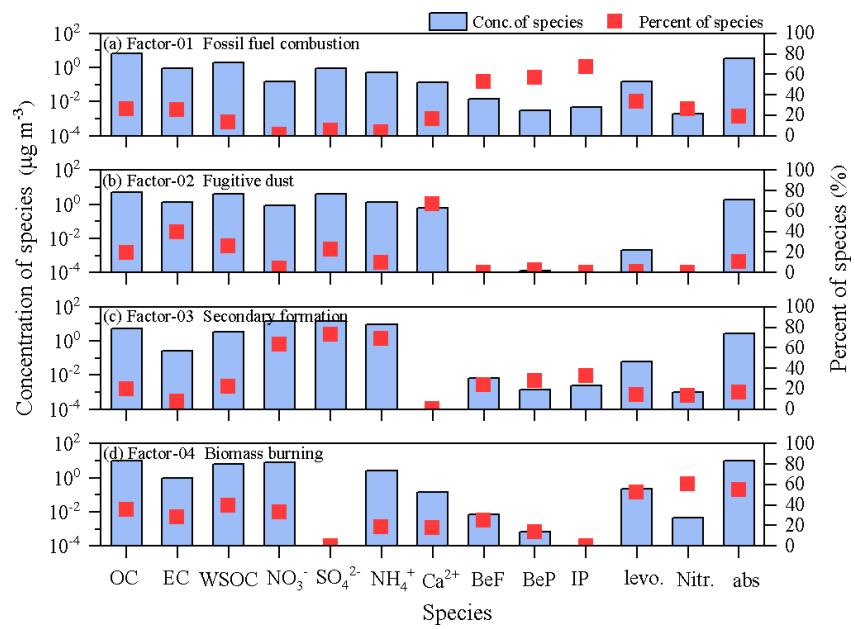

Figure 7. Factor profiles resolved by PMF mode during the winter and summer sampling period. The bars represent the concentrations of species and the dots represent the contributions of species appointed to the factors (the summer and winter samples were merged together for the PMF analysis due to the limited number of samples).

$\mathrm{BeP}(57 \%)$ and IP (67\%), which were primarily derived from coal combustion and vehicle exhausts (Kong et al., 2010; Ma et al., 2010; Harrison et al., 1996); further, relatively high OC (29\%) and EC (25\%) associated with this factor are well-known tracers of exhaust emissions (Zong et al., 2016), so we identified factor 01 as the source from fossil fuel combustion. Factor 02 (fugitive dust) shows a high contribution of $\mathrm{Ca}^{2+}(69 \%)$ and a moderate loading of EC $(39 \%)$. Ca, as one of the most abundant crustal elements, is largely from construction work, resuspended dust or soil sources (Chow et al., 2004; Han et al., 2007). In addition, EC is a well-known tracer of vehicular emissions (Dorado et al., 2003), so this factor can be attributed to the impact of vehicles passing with higher speeds, leading to resuspended nontailpipe particles. Moreover, the concentrations of $\mathrm{Ca}^{2+}$ in the night were almost higher than those during the daytime, with averages of $1.8 \pm 1.56$ and $1.43 \pm 0.85 \mathrm{\mu g} \mathrm{m}^{-3}$, respectively. This is consistent with the time for transporting the construction waste by lorry. Thus, factor 02 was identified as fugitive dust. Factor 03 was identified as secondary formation, as it is associated with high loadings of $\mathrm{NO}_{3}^{-}(63 \%)$, $\mathrm{SO}_{4}^{2-}(73 \%)$ and $\mathrm{NH}_{4}^{+}(69 \%)$ and a moderate loading of $\mathrm{OC}$ and WSOC, indicating the presence of secondary inorganic and organic aerosols. Factor 04 showed high loadings with nitrophenols, levoglucosan and abs- $\mathrm{MeOH}$ and was identified as biomass burning, because levoglucosan is the tracer for biomass burning smoke, and nitrophenols can be produced in the aging process of biomass burning plumes.

Figure 8 shows the contributions of the above sources to the light absorption at $\lambda=365 \mathrm{~nm}$, which also represents the fraction of $\mathrm{BrC}$ for the factors. Biomass burning was the pri-

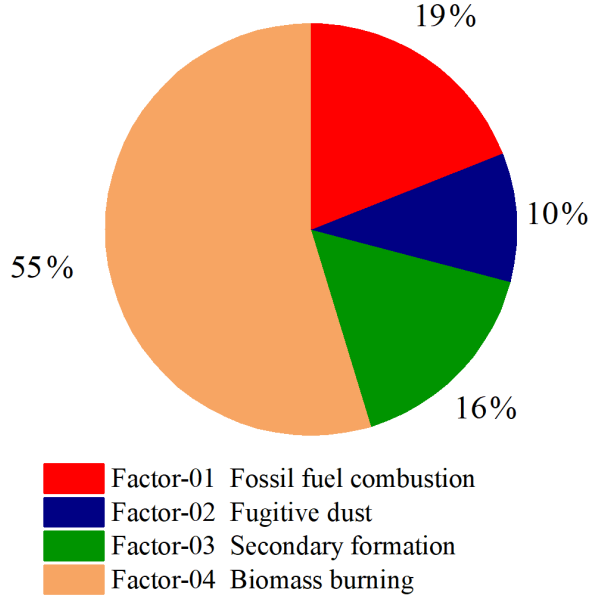

Figure 8. Source apportionment for airborne fine particulate $\mathrm{BrC}$ in $\mathrm{Xi}$ 'an during the campaign.

mary source of the $\mathrm{BrC}$, accounting for $55 \%$ of the total $\mathrm{BrC}$ in the city, which is coincided with the results discussed in the Sect. 3.2.1. A significant fraction (about 19\%) of $\mathrm{BrC}$ was associated with fossil fuel combustion. The fraction of secondary $\mathrm{BrC}$ was about $16 \%$, which was enhanced during the summer due to the efficient photochemical formation of secondary chromophores. The AAE value of total $\mathrm{BrC}$, closed to the aged SOA-AAE (4.7-5.3) (Bones et al., 2010), can also verify it. The remaining fraction of $\mathrm{BrC}$ was derived from the fugitive dust in the city. The results of $\mathrm{BrC}$ source apportionment for the Xi' an samples are in line with the work by Shen et al. (2017) and also similar to the results obtained in Beijing by using radiocarbon fingerprinting (Yan et al., 2017).

\section{Conclusions}

This study investigated the seasonality of the light absorption characteristics of $\mathrm{BrC}$ in Xi' an. The light absorption coefficient (MAC) of methanol extracts at $365 \mathrm{~nm}$ was 1.5 1.7-fold higher than water extracts in the two seasons, suggesting nonpolar compounds in the city are of stronger light-absorbing ability than that of polar compounds. The strong correlation of levoglucosan with $\mathrm{BrC}$ and the diagnostic ratios of levoglucosan/mannosan and levoglucosan / galacosan revealed that the wintertime abundant $\mathrm{BrC}$ $\left(\operatorname{abs}_{\lambda}=365 \mathrm{~nm}-\mathrm{MeOH}\right.$ of $\left.49.18 \pm 31.67 \mathrm{M} \mathrm{m}^{-1}\right)$ in Xi' an was mainly derived from the residential biofuel combustion for house heating in the city and its surrounding region. Size distribution results showed that $81 \%$ and $65 \%$ of $\mathrm{BrC}$ occurred in the fine mode $(<2.1 \mu \mathrm{m})$ during winter and summer, respectively, which is characterized by a monomodal size distribution with a peak in winter and a bimodal size distribution in summer with two peaks in the fine and coarse modes. The fine mode of MAC is $50 \%$ higher in winter than in summer, 
suggesting that the light-absorbing ability of wintertime fine particles is stronger, due to the abundant occurrence of PAHs and other aromatic compounds in the fine mode.

The linear correlation between the ratio of $\mathrm{abs}_{\lambda}=365 \mathrm{~nm}^{-}$

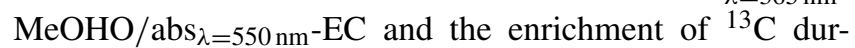
ing the haze development indicated an accumulation of secondary $\mathrm{BrC}$ in the aerosol aging process. The daytime strong correlation of the ratio of $\operatorname{abs}_{\lambda}=365 \mathrm{~nm}^{-} \mathrm{MeOHO} / \mathrm{abs}_{\lambda}=550 \mathrm{~nm}^{-}$ EC with nitrophenols in the haze event further revealed that such an enhanced production of secondary $\mathrm{BrC}$ is related to the photooxidation of aromatic compounds with $\mathrm{NO}_{x}$. Source apportionment by using PMF showed that $55 \%$ of the $\mathrm{BrC}$ was associated with biomass burning in the city during the campaign, with $19 \%$ and $16 \%$ of $\mathrm{BrC}$ derived from fossil fuel combustion and secondary formation, respectively.

Data availability. Data can be accessed by contacting the corresponding author.

Supplement. The supplement related to this article is available online at: https://doi.org/10.5194/acp-20-2017-2020-supplement.

Author contributions. GW designed the experiment. CW, JiaL, JinL and CC collected the samples. CW and ZZ conducted the experiments. $\mathrm{CW}, \mathrm{GW}$ and JC performed the data interpretation, and $\mathrm{CW}$ and GW wrote the paper. SG, YX, XL, GX, XW and FC contributed to the paper with useful scientific discussions or comments.

Competing interests. The authors declare that they have no conflict of interest.

Special issue statement. This article is part of the special issue "Multiphase chemistry of secondary aerosol formation under severe haze". It is not associated with a conference.

Acknowledgements. This work was financially supported by the National Key R\&D Programme "Quantitative Relationship and Regulation Principle between Regional Oxidation Capacity of Atmospheric and Air Quality" (no. 2017YFC0210000) and the a program from the National Nature Science Foundation of China (no. 41773117).

Financial support. This research has been supported by the Quantitative Relationship and Regulation Principle between Regional Oxidation Capacity of Atmospheric and Air Quality (grant no. 2017YFC0210000) and the program from the National Nature Science Foundation of China (grant no. 41773117).
Review statement. This paper was edited by Aijun Ding and reviewed by three anonymous referees.

\section{References}

Andreae, M. O. and Ramanathan, V.: Climate change. Climate's dark forcings, Science, 340, 280-281, https://doi.org/10.1126/science.1235731, 2013.

Bachi, S.: Mass absorption efficiency of light absorbing organic aerosols from source region of paddy-residue burning emissions in the Indo-Gangetic Plain, Atmos. Environ., 125, 360-370, https://doi.org/10.1016/j.atmosenv.2015.07.017, 2016.

Bluvshtein, N., Lin, P., Flores, J. M., Segev, L., Mazar, Y., Tas, E., Snider, G., Weagle, C., Brown, S. S., and Laskin, A.: Broadband optical properties of biomass burning aerosol and identification of brown carbon chromophores, J. Geophys. Res., 122, 54415456, https://doi.org/10.1002/2016JD026230, 2017.

Bones, D. L., Henricksen, D. K., Mang, S. A., Gonsior, M., Bateman, A. P., Nguyen, T. B., Cooper, W. J., and Nizkorodov, S. A.: Appearance of strong absorbers and fluorophores in limoneneO3secondary organic aerosol due to $\mathrm{NH}_{4}^{+}$-mediated chemical aging over long time scales, J. Geophys. Res., 115, D05203, https://doi.org/10.1029/2009jd012864, 2010.

Cao, F., Zhang, S.-C., Kawamura, K., and Zhang, Y.-L.: Inorganic markers, carbonaceous components and stable carbon isotope from biomass burning aerosols in Northeast China, Sci. Total Environ., 572, 1244-1251, https://doi.org/10.1016/j.scitotenv.2015.09.099, 2016.

Chakrabarty, R. K., Moosmüller, H., Chen, L.-W. A., Lewis, K., Arnott, W. P., Mazzoleni, C., Dubey, M. K., Wold, C. E., Hao, W. M., and Kreidenweis, S. M.: Brown carbon in tar balls from smoldering biomass combustion, Atmos. Chem. Phys., 10, 63636370, https://doi.org/10.5194/acp-10-6363-2010, 2010.

Chen, Y. and Bond, T. C.: Light absorption by organic carbon from wood combustion, Atmos. Chem. Phys., 10, 1773-1787, https://doi.org/10.5194/acp-10-1773-2010, 2010.

Chen, Y., Ge, X., Chen, H., Xie, X., Chen, Y., Wang, J., Ye, Z., Bao, M., Zhang, Y., and Chen, M.: Seasonal light absorption properties of water-soluble brown carbon in atmospheric fine particles in Nanjing, China, Atmos. Environ., 187, 230-240, https://doi.org/10.1016/j.atmosenv.2018.06.002, 2018.

Cheng, Y., He, K. B., Du, Z. Y., Engling, G., Liu, J. M., Ma, Y. L., Zheng, M., and Weber, R. J.: The characteristics of brown carbon aerosol during winter in Beijing, Atmos. Environ., 127, 355-364, https://doi.org/10.1016/j.atmosenv.2015.12.035, 2016.

Chow, J. C., Watson, J. G., Kuhns, H., Etyemezian, V., Lowenthal, D. H., Crow, D., Kohl, S. D., Engelbrecht, J. P., and Green, M. C.: Source profiles for industrial, mobile, and area sources in the Big Bend Regional Aerosol Visibility and Observational study, Chemosphere, 54, 185-208, https://doi.org/10.1016/j.chemosphere.2003.07.004, 2004.

Chow, J. C., Watson, J. G., Chen, L. W., Chang, M. C., Robinson, N. F., Trimble, D., and Kohl, S.: The IMPROVE - A temperature protocol for thermal/optical carbon analysis: maintaining consistency with a long-term database, J. Air Waste Manage., 57, 1014-1023, https://doi.org/10.3155/1047-3289.57.9.1014, 2007.

Chung, C. E., Ramanathan, V., and Decremer, D.: Observationallyconstrained Estimates of Carbonaceous Aerosol Radiative 
Forcing, P. Natl. Acad. Sci. USA, 109, 11624-11629, https://doi.org/10.1073/pnas.1203707109, 2012.

Cochran, R. E., Jeong, H., Haddadi, S., Fisseha Derseh, R., Gowan, A., Beránek, J., and Kubátová, A.: Identification of products formed during the heterogeneous nitration and ozonation of polycyclic aromatic hydrocarbons, Atmos. Environ., 128, 92-103, https://doi.org/10.1016/j.atmosenv.2015.12.036, 2016.

Collier, S., Williams, L. R., Onasch, T. B., Cappa, C. D., Zhang, X., Russell, L. M., Chen, C.-L., Sanchez, K. J., Worsnop, D. R., and Zhang, Q.: Influence of Emissions and Aqueous Processing on Particles Containing Black Carbon in a Polluted Urban Environment: Insights From a Soot Particle-Aerosol Mass Spectrometer, J. Geophys. Res.-Atmos., 123, 6648-6666, https://doi.org/10.1002/2017jd027851, 2018.

Corr, C. A., Hall, S. R., Ullmann, K., Anderson, B. E., Beyersdorf, A. J., Thornhill, K. L., Cubison, M. J., Jimenez, J. L., Wisthaler, A., and Dibb, J. E.: Spectral absorption of biomass burning aerosol determined from retrieved single scattering albedo during ARCTAS, Atmos. Chem. Phys., 12, 10505-10518, https://doi.org/10.5194/acp-12-10505-2012, 2012.

Ding, X., Zheng, M., Yu, L., Zhang, X., Weber, R. J., Yan, B., Russell, A. G., Edgerton, E. S., and Wang, X.: Spatial and Seasonal Trends in Biogenic Secondary Organic Aerosol Tracers and Water-Soluble Organic Carbon in the Southeastern United States, Environ. Sci. Technol., 42, 5171-5176, https://doi.org/10.1021/es7032636, 2008.

Dorado, M. P., Ballesteros, E., Arnal, J. M., Gómez, J., and López, F. J.: Exhaust emissions from a Diesel engine fueled with transesterified waste olive oil?, Fuel, 82, 1311-1315, https://doi.org/10.1016/S0016-2361(03)00034-6, 2003.

Du, Z., He, K., Cheng, Y., Duan, F., Ma, Y., Liu, J., Zhang, X., Zheng, M., and Weber, R.: A yearlong study of water-soluble organic carbon in Beijing II: Light absorption properties, Atmos. Environ., 89, 235-241, https://doi.org/10.1016/j.atmosenv.2014.02.022, 2014.

Flores, J. M., Washenfelder, R. A., Adler, G., Lee, H. J., Segev, L., Laskin, J., Laskin, A., Nizkorodov, S. A., Brown, S. S., and Rudich, Y.: Complex refractive indices in the near-ultraviolet spectral region of biogenic secondary organic aerosol aged with ammonia, Phys. Chem. Chem. Phys., 16, 10629-10642, https://doi.org/10.1039/c4cp01009d, 2014.

Gilardoni, S., Massoli, P., Paglione, M., Giulianelli, L., Carbone, C., Rinaldi, M., Decesari, S., Sandrini, S., Costabile, F., Gobbi, G. P., Pietrogrande, M. C., Visentin, M., Scotto, F., Fuzzi, S., and Facchini, M. C.: Direct observation of aqueous secondary organic aerosol from biomassburning emissions, P. Natl. Acad. Sci. USA, 113, 10013-10018, https://doi.org/10.1073/pnas.1602212113, 2016.

Gustafsson, O., Kruså, M., Zencak, Z., Sheesley, R. J., Granat, L., Engström, E., Praveen, P. S., Rao, P. S., Leck, C., and Rodhe, H.: Brown clouds over South Asia: biomass or fossil fuel combustion?, Science, 323, 495-498, https://doi.org/10.1126/science.1164857, 2009.

Han, L., Zhuang, G., Cheng, S., Wang, Y., and Li, J.: Characteristics of re-suspended road dust and its impact on the atmospheric environment in Beijing, Atmos. Environ., 41, 74857499, https://doi.org/10.1016/j.atmosenv.2007.05.044, 2007.

Harrison, R. M., Smith, D. J. T., and Luhana, L.: Source Apportionment of Atmospheric Polycyclic Aromatic Hydrocarbons Col- lected from an Urban Location in Birmingham, U.K, Environ. Sci. Technol., 30, 825-832, https://doi.org/10.1021/es950252d, 1996.

Hecobian, A., Zhang, X., Zheng, M., Frank, N., Edgerton, E. S., and Weber, R. J.: Water-Soluble Organic Aerosol material and the light-absorption characteristics of aqueous extracts measured over the Southeastern United States, Atmos. Chem. Phys., 10, 5965-5977, https://doi.org/10.5194/acp-10-5965-2010, 2010.

Hsu, H. I., Lin, M. Y., Chen, Y. C., Chen, W. Y., Yoon, C., Chen, M. R., and Tsai, P. J.: An integrated approach to assess exposure and health-risk from polycyclic aromatic hydrocarbons (PAHs) in a fastener manufacturing industry, Int. J. Env. Res. Pub. He., 11, 9578-9594, https://doi.org/10.3390/ijerph110909578, 2014.

Huang, R. J., Yang, L., Cao, J., Chen, Y., Chen, Q., Li, Y., Duan, J., Zhu, C., Dai, W., and Wang, K.: Brown Carbon Aerosol in Urban Xi'an, Northwest China: The Composition and Light Absorption Properties, Environ. Sci. Technol., 52, 6825-6833, https://doi.org/10.1021/acs.est.8b02386, 2018.

Jo, D. S., Park, R. J., Lee, S., Kim, S.-W., and Zhang, X.: A global simulation of brown carbon: implications for photochemistry and direct radiative effect, Atmos. Chem. Phys., 16, 3413-3432, https://doi.org/10.5194/acp-16-3413-2016, 2016.

Keyte, I. J., Harrison, R. M., and Lammel, G.: Chemical reactivity and long-range transport potential of polycyclic aromatic hydrocarbons - a review, Chem. Soc. Rev., 42, 9333-9391, https://doi.org/10.1039/c3cs60147a, 2013.

Kim, H., Jin, Y. K., Jin, H. C., Ji, Y. L., and Lee, S. P.: Seasonal variations in the light-absorbing properties of water-soluble and insoluble organic aerosols in Seoul, Korea, Atmos. Environ., 129, 234-242, https://doi.org/10.1016/j.atmosenv.2016.01.042, 2016.

Kirillova, E. N., Andersson, A., Tiwari, S., Srivastava, A. K., Bisht, D. S., and Örjan, G.: Water-soluble organic carbon aerosols during a full New Delhi winter: Isotope-based source apportionment and optical properties, J. Geophys. Res.-Atmos., 119, 34763485, https://doi.org/10.1002/2013JD020041, 2014.

Kong, S., Ding, X., Bai, Z., Han, B., Chen, L., Shi, J., and $\mathrm{Li}, \mathrm{Z}$ : : A seasonal study of polycyclic aromatic hydrocarbons in $\mathrm{PM}_{2.5}$ and $\mathrm{PM}_{2.5-10}$ in five typical cities of Liaoning Province, China, J. Hazard Mater., 183, 70-80, https://doi.org/10.1016/j.jhazmat.2010.06.107, 2010.

Laskin, A., Laskin, J., and Nizkorodov, S. A.: Chemistry of atmospheric brown carbon, Chem. Rev., 115, 4335-4382, https://doi.org/10.1021/cr5006167, 2015.

Lee, H. J., Aiona, P. K., Laskin, A., Laskin, J., and Nizkorodov, S. A.: Effect of solar radiation on the optical properties and molecular composition of laboratory proxies of atmospheric brown carbon, Environ. Sci. Technol., 48, 10217-10226, https://doi.org/10.1021/es502515r, 2014.

Lei, Y., Shen, Z., Zhang, T., Zhang, Q., Wang, Q., Sun, J., Gong, X., Cao, J., Xu, H., and Liu, S.: Optical source profiles of brown carbon in size-resolved particulate matter from typical domestic biofuel burning over Guanzhong Plain, China, Sci. Total Environ., 622, 244-251, https://doi.org/10.1016/j.scitotenv.2017.11.353, 2018.

Lin, G., Penner, J. E., Flanner, M. G., Sillman, S., Xu, L., and Zhou, C.: Radiative forcing of organic aerosol in the atmosphere and on snow: Effects of SOA and brown carbon, J. Geophys. Res.Atmos., 119, 7453-7476, https://doi.org/10.1002/2013jd021186, 2014. 
Lin, P., Liu, J., Shilling, J. E., Kathmann, S. M., Laskin, J., and Laskin, A.: Molecular characterization of brown carbon $(\mathrm{BrC})$ chromophores in secondary organic aerosol generated from photo-oxidation of toluene, Phys. Chem. Chem. Phys., 17, 23312-23325, https://doi.org/10.1039/c5cp02563j, 2015.

Lin, P., Aiona, P. K., Li, Y., Shiraiwa, M., Laskin, J., Nizkorodov, S. A., and Laskin, A.: Molecular Characterization of Brown Carbon in Biomass Burning Aerosol Particles, Environ. Sci. Technol., 50, 11815-11824, https://doi.org/10.1021/acs.est.6b03024, 2016.

Lin, P., Bluvshtein, N., Rudich, Y., Nizkorodov, S. A., Laskin, J., and Laskin, A.: Molecular Chemistry of Atmospheric Brown Carbon Inferred from a Nationwide Biomass Burning Event, Environ. Sci. Technol., 51, 11561-11570, https://doi.org/10.1021/acs.est.7b02276, 2017.

Liu, J., Bergin, M., Guo, H., King, L., Kotra, N., Edgerton, E., and Weber, R. J.: Size-resolved measurements of brown carbon in water and methanol extracts and estimates of their contribution to ambient fine-particle light absorption, Atmos. Chem. Phys., 13, 12389-12404, https://doi.org/10.5194/acp-13-123892013, 2013.

Liu, J., Lin, P., Laskin, A., Laskin, J., Kathmann, S. M., Wise, M., Caylor, R., Imholt, F., Selimovic, V., and Shilling, J. E.: Optical properties and aging of light-absorbing secondary organic aerosol, Atmos. Chem. Phys., 16, 12815-12827, https://doi.org/10.5194/acp-16-12815-2016, 2016.

Liu, J., Mo, Y., Ding, P., Li, J., Shen, C., and Zhang, G.: Dual carbon isotopes $\left({ }^{14} \mathrm{C}\right.$ and $\left.{ }^{13} \mathrm{C}\right)$ and optical properties of WSOC and HULIS-C during winter in Guangzhou, China, Sci. Total Environ., 633, 1571-1578, https://doi.org/10.1016/j.scitotenv.2018.03.293, 2018.

Lorenzo, R. D., Place, B. K., Vandenboer, T. C., and Young, C. J.: Composition of Size-Resolved Aged Boreal Fire Aerosols: Brown Carbon, Biomass Burning Tracers, and Reduced Nitrogen, ACS Earth and Space Chemistry, 2, 278-285, https://doi.org/10.1021/acsearthspacechem.7b00137, 2018.

Ma, W. L., Li, Y. F., Qi, H., Sun, D. Z., Liu, L. Y., and Wang, D. G.: Seasonal variations of sources of polycyclic aromatic hydrocarbons (PAHs) to a northeastern urban city, China, Chemosphere, 79, 441-447, https://doi.org/10.1016/j.chemosphere.2010.01.048, 2010.

Miyazaki, Y., Kondo, Y., Takegawa, N., Komazaki, Y., Fukuda, M., Kawamura, K., Mochida, M., Okuzawa, K., and Weber, R. J.: Time-resolved measurements of water-soluble organic carbon in Tokyo, J. Geophys. Res.-Atmos., 111, D23206, https://doi.org/10.1029/2006JD007125, 2006.

Moosmuller, H., Chakrabarty, R. K., and Arnott, W. P.: Aerosol light absorption and its measurement: A review, J. Quant. Spectrosc. Ra., 110, 844-878, https://doi.org/10.1016/j.jqsrt.2009.02.035, 2009.

Nakayama, T., Sato, K., Matsumi, Y., Imamura, T., Yamazaki, A., and Uchiyama, A.: Wavelength and $\mathrm{NO}_{\mathrm{x}}$ dependent complex refractive index of SOAs generated from the photooxidation of toluene, Atmos. Chem. Phys., 13, 531-545, https://doi.org/10.5194/acp-13-531-2013, 2013.

Nguyen-Duy, D. and Chang, M. B.: Review on characteristics of PAHs in atmosphere, anthropogenic sources and control technologies, Sci. Total Environ., 609, 682-693, https://doi.org/10.1016/j.scitotenv.2017.07.204, 2017.
Pavuluri, C. M., Kawamura, K., and Swaminathan, T.: Timeresolved distributions of bulk parameters, diacids, ketoacids and $\alpha$-dicarbonyls and stable carbon and nitrogen isotope ratios of TC and TN in tropical Indian aerosols: Influence of land/sea breeze and secondary processes, Atmos. Res., 153, 188-199, https://doi.org/10.1016/j.atmosres.2014.08.011, 2015.

Peng, J., Hu, M., Guo, S., Du, Z., Zheng, J., Shang, D., Zamora, M. L., Zeng, L., Shao, M., Wu, Y.-S., Zheng, J., Wang, Y., Glen, C. R., Collins, D. R., Molina, M. J., and Zhang, R.: Markedly enhanced absorption and direct radiative forcing of black carbon under polluted urban environments, P. Natl. Acad. Sci. USA, 113, 4266-4271, https://doi.org/10.1073/pnas.1602310113, 2016.

Ping, X., Zhou, X., Duan, J., Tan, J., He, K., Yuan, C., Ma, Y., and Zhang, Y.: Chemical characteristics of watersoluble organic compounds (WSOC) in $\mathrm{PM}_{2.5}$ in Beijing, China: 2011-2012, Atmos. Res., 183, 104-112, https://doi.org/10.1016/j.atmosres.2016.08.020, 2017.

Qian, Y., Yasunari, T. J., Doherty, S. J., Flanner, M. G., Lau, W. K. M., Ming, J., Wang, H., Wang, M., Warren, S. G., and Zhang, R.: Light-absorbing particles in snow and ice: Measurement and modeling of climatic and hydrological impact, Adv. Atmos. Sci., 32, 64-91, https://doi.org/10.1007/s00376-014-0010-0, 2015.

Ren, Y., Wang, G., Wu, C., Wang, J., Li, J., Zhang, L., Han, Y., Liu, L., Cao, C., Cao, J., He, Q., and Liu, $\mathrm{X}$.: Changes in concentration, composition and source contribution of atmospheric organic aerosols by shifting coal to natural gas in Urumqi, Atmos. Environ., 148, 306-315, https://doi.org/10.1016/j.atmosenv.2016.10.053, 2017.

Saleh, R., Hennigan, C. J., McMeeking, G. R., Chuang, W. K., Robinson, E. S., Coe, H., Donahue, N. M., and Robinson, A. L.: Absorptivity of brown carbon in fresh and photo-chemically aged biomass-burning emissions, Atmos. Chem. Phys., 13, 76837693, https://doi.org/10.5194/acp-13-7683-2013, 2013.

Saleh, R., Robinson, E. S., Tkacik, D. S., Ahern, A. T., Liu, S., Aiken, A. C., Sullivan, R. C., Presto, A. A., Dubey, M. K., Yokelson, R. J., Donahue, N. M., and Robinson, A. L.: Brownness of organics in aerosols from biomass burning linked to their black carbon content, Nat. Geosci., 7, 647-650, https://doi.org/10.1038/ngeo2220, 2014.

Satish, R. V., Shamjad, P. M., Thamban, N. M., Tripathi, S. N., and Rastogi, N.: Temporal Characteristics of Brown Carbon over the Central Indo-Gangetic Plain, Environ. Sci. Technol., 51, 67656772, https://doi.org/10.1021/acs.est.7b00734, 2017.

Shamjad, P. M., Satish, R. V., Thamban, N. M., Rastogi, N., and Tripathi, S. N.: Absorbing Refractive Index and Direct Radiative Forcing of Atmospheric Brown Carbon over Gangetic Plain, ACS Earth and Space Chemistry, 2, 31-37, https://doi.org/10.1021/acsearthspacechem.7b00074, 2017.

Shen, G., Tao, S., Wei, S., Chen, Y., Zhang, Y., Shen, H., Huang, Y., Zhu, D., Yuan, C., Wang, H., Wang, Y., Pei, L., Liao, Y., Duan, Y., Wang, B., Wang, R., Lv, Y., Li, W., Wang, $\mathrm{X}$., and Zheng, X.: Field measurement of emission factors of PM, EC, OC, parent, nitro-, and oxy-polycyclic aromatic hydrocarbons for residential briquette, coal cake, and wood in rural Shanxi, China, Environ. Sci. Technol., 47, 2998-3005, https://doi.org/10.1021/es304599g, 2013.

Shen, Z., Zhang, Q., Cao, J., Zhang, L., Lei, Y., Huang, Y., Huang, R. J., Gao, J., Zhao, Z., Zhu, C., Yin, X., Zheng, C., Xu, H., and Liu, S.: Optical properties and possible sources of brown 
carbon in $\mathrm{PM}_{2.5}$ over Xi' an, China, Atmos. Environ., 150, 322 330, https://doi.org/10.1016/j.atmosenv.2016.11.024, 2017.

Smith, J. D., Sio, V., Yu, L., Zhang, Q., and Anastasio, C.: Secondary organic aerosol production from aqueous reactions of atmospheric phenols with an organic triplet excited state, Environ. Sci. Technol., 48, 1049-1057, doi:10.1021/es4045715, 2014.

Sumlin, B. J., Pandey, A., Walker, M. J., Pattison, R. S., Williams, B. J., and Chakrabarty, R. K.: Atmospheric Photooxidation Diminishes Light Absorption by Primary Brown Carbon Aerosol from Biomass Burning, Environ. Sci. Tech. Lett., 4, 540-545, https://doi.org/10.1021/acs.estlett.7b00393, 2017.

Sun, J., Zhi, G., Hitzenberger, R., Chen, Y., Tian, C., Zhang, Y., Feng, Y., Cheng, M., Zhang, Y., Cai, J., Chen, F., Qiu, Y., Jiang, Z., Li, J., Zhang, G., and Mo, Y.: Emission factors and light absorption properties of brown carbon from household coal combustion in China, Atmos. Chem. Phys., 17, 4769-4780, https://doi.org/10.5194/acp-17-4769-2017, 2017.

Teich, M., van Pinxteren, D., Wang, M., Kecorius, S., Wang, Z., Müller, T., Močnik, G., and Herrmann, H.: Contributions of nitrated aromatic compounds to the light absorption of watersoluble and particulate brown carbon in different atmospheric environments in Germany and China, Atmos. Chem. Phys., 17, 1653-1672, https://doi.org/10.5194/acp-17-1653-2017, 2017.

Wang, D., Tian, F., Yang, M., Liu, C., and Li, Y. F.: Application of positive matrix factorization to identify potential sources of PAHs in soil of Dalian, China, Environ. Pollut., 157, 1559-1564, https://doi.org/10.1016/j.envpol.2009.01.003, 2009a.

Wang, G., Kawamura, K., Xie, M., Hu, S., Gao, S., Cao, J., An, Z., and Wang, Z.: Size-distributions of $n$-alkanes, PAHs and hopanes and their sources in the urban, mountain and marine atmospheres over East Asia, Atmos. Chem. Phys., 9, 8869-8882, https://doi.org/10.5194/acp-9-8869-2009, 2009 b.

Wang, G., Xie, M., Hu, S., Gao, S., Tachibana, E., and Kawamura, K.: Dicarboxylic acids, metals and isotopic compositions of $\mathrm{C}$ and $\mathrm{N}$ in atmospheric aerosols from inland China: implications for dust and coal burning emission and secondary aerosol formation, Atmos. Chem. Phys., 10, 6087-6096, https://doi.org/10.5194/acp-10-6087-2010, 2010.

Wang, G., Zhang, R., Gomez, M. E., Yang, L., Zamora, M. L., Hu, M., Lin, Y., Peng, J., Guo, S., Meng, J., Li, J., Cheng, C., Hu, T., Ren, Y., Wang, Y., Gao, J., Cao, J., An, Z., Zhou, W., Li, G., Wang, J., Tian, P., Marrero-Ortiz, W., Secrest, J., Du, Z., Zheng, J., Shang, D., Zeng, L., Shao, M., Wang, W., Huang, Y., Wang, Y., Zhu, Y., Li, Y., Hu, J., Pan, B., Cai, L., Cheng, Y., Ji, Y., Zhang, F., Rosenfeld, D., Liss, P. S., Duce, R. A., Kolb, C. E., and Molina, M. J.: Persistent sulfate formation from London Fog to Chinese haze, P. Natl. Acad. Sci. USA, 113, 13630-13635, https://doi.org/10.1073/pnas.1616540113, 2016.

Wang, G. H., Zhou, B. H., Cheng, C. L., Cao, J. J., Li, J. J., Meng, J. J., Tao, J., Zhang, R. J., and Fu, P. Q.: Impact of Gobi desert dust on aerosol chemistry of Xi'an, inland China during spring 2009: differences in composition and size distribution between the urban ground surface and the mountain atmosphere, Atmos. Chem. Phys., 13, 819-835, https://doi.org/10.5194/acp-13-8192013, 2013.

Wang, J., Cao, J., Dong, Z., Guinot, B., Gao, M., Huang, R., Han, Y., Huang, Y., Ho, S., and Shen, Z.: Seasonal variation, spatial distribution and source apportionment for polycyclic aromatic hydrocarbons (PAHs) at nineteen communities in Xi'an, China: The ef- fects of suburban scattered emissions in winter, Environ. Pollut., 231, 1330-1343, https://doi.org/10.1016/j.envpol.2017.08.106, 2017.

Wang, X., Heald, C. L., Ridley, D. A., Schwarz, J. P., Spackman, J. R., Perring, A. E., Coe, H., Liu, D., and Clarke, A. D.: Exploiting simultaneous observational constraints on mass and absorption to estimate the global direct radiative forcing of black carbon and brown carbon, Atmos. Chem. Phys., 14, 10989-11010, https://doi.org/10.5194/acp-14-10989-2014, 2014.

Wu, C., Wang, G., Wang, J., Li, J., Ren, Y., Zhang, L., Cao, C., Li, J., Ge, S., and Xie, Y.: Chemical characteristics of haze particles in Xi'an during Chinese Spring Festival: Impact of fireworks burning, J. Environ. Sci., 71, 179-187, https://doi.org/10.1016/j.jes.2018.04.008, 2018.

Wu, C., Wang, G., Cao, C., Li, J., Li, J., Wu, F., Huang, R., Cao, J., Han, Y., Ge, S., Xie, Y., Xue, G., and Wang, X.: Chemical characteristics of airborne particles in Xi' an, inland China during dust storm episodes: Implications for heterogeneous formation of ammonium nitrate and enhancement of N-deposition, Environ. Pollut., 244, 877-884, https://doi.org/10.1016/j.envpol.2018.10.019, 2019.

Xie, M., Chen, X., Hays, M. D., Lewandowski, M., Offenberg, J., Kleindienst, T. E., and Holder, A. L.: Light Absorption of Secondary Organic Aerosol: Composition and Contribution of Nitroaromatic Compounds, Environ. Sci. Technol., 51, 1160711616, https://doi.org/10.1021/acs.est.7b03263, 2017.

Xie, M., Shen, G., Holder, A. L., Hays, M. D., and Jetter, J. J.: Light absorption of organic carbon emitted from burning wood, charcoal, and kerosene in household cookstoves, Environ. Pollut., 240, 60-67, https://doi.org/10.1016/j.envpol.2018.04.085, 2018.

Yan, C., Zheng, M., Sullivan, A. P., Bosch, C., Desyaterik, Y., Andersson, A., Li, X., Guo, X., Zhou, T., and Örjan, G.: Chemical characteristics and light-absorbing property of water-soluble organic carbon in Beijing: Biomass burning contributions, Atmos. Environ., 121, 412, https://doi.org/10.1016/j.atmosenv.2015.05.005, 2015.

Yan, C., Zheng, M., Bosch, C., Andersson, A., Desyaterik, Y., Sullivan, A. P., Collett, J. L., Zhao, B., Wang, S., He, K., and Gustafsson, O.: Important fossil source contribution to brown carbon in Beijing during winter, Sci. Rep.-UK, 7, 43182, https://doi.org/10.1038/srep43182, 2017.

Yan, J., Wang, X., Gong, P., Wang, C., and Cong, Z.: Review of brown carbon aerosols: Recent progress and perspectives, Sci. Total Environ., 634, 1475-1485, https://doi.org/10.1016/j.scitotenv.2018.04.083, 2018.

Yang, H., Xu, J., Wu, W. S., Wan, C. H., and Yu, J. Z.: Chemical Characterization of Water-Soluble Organic Aerosols at Jeju Island Collected During ACE-Asia, Environ. Chem., 1, 13-17, https://doi.org/10.1071/EN04006, 2004.

Yuan, B., Liggio, J., Wentzell, J., Li, S.-M., Stark, H., Roberts, J. M., Gilman, J., Lerner, B., Warneke, C., Li, R., Leithead, A., Osthoff, H. D., Wild, R., Brown, S. S., and de Gouw, J. A.: Secondary formation of nitrated phenols: insights from observations during the Uintah Basin Winter Ozone Study (UBWOS) 2014, Atmos. Chem. Phys., 16, 2139-2153, https://doi.org/10.5194/acp16-2139-2016, 2016.

Zhai, J., Lu, X., Li, L., Zhang, Q., Zhang, C., Chen, H., Yang, X., and Chen, J.: Size-resolved chemical composition, effective density, and optical properties of biomass burning particles, At- 
mos. Chem. Phys., 17, 7481-7493, https://doi.org/10.5194/acp17-7481-2017, 2017.

Zhang, X., Hecobian, A., Zheng, M., Frank, N. H., and Weber, R. J.: Biomass burning impact on $\mathrm{PM}_{2.5}$ over the southeastern US during 2007: integrating chemically speciated FRM filter measurements, MODIS fire counts and PMF analysis, Atmos. Chem. Phys., 10, 6839-6853, https://doi.org/10.5194/acp10-6839-2010, 2010.

Zhang, X., Lin, Y. H., Surratt, J. D., Zotter, P., Prévôt, A. S. H., and Weber, R. J.: Light-absorbing soluble organic aerosol in Los Angeles and Atlanta: A contrast in secondary organic aerosol, Geophys. Res. Lett., 38, 759-775, https://doi.org/10.1029/2011GL049385, 2011.

Zhang, Y. and Tao, S.: Global atmospheric emission inventory of polycyclic aromatic hydrocarbons (PAHs) for 2004, Atmos. Environ., 43, 812-819, https://doi.org/10.1016/j.atmosenv.2008.10.050, 2009.

Zhang, Z., Gao, J., Engling, G., Tao, J., Chai, F., Zhang, L., Zhang, R., Sang, X., Chan, C. Y., and Lin, Z.: Characteristics and applications of size-segregated biomass burning tracers in China's Pearl River Delta region, Atmos. Environ., 102, 290301, https://doi.org/10.1016/j.atmosenv.2014.12.009, 2015.
Zhao, M., Huang, Z., Qiao, T., Zhang, Y., Xiu, G., and Yu, J.: Chemical characterization, the transport pathways and potential sources of $\mathrm{PM}_{2.5}$ in Shanghai: Seasonal variations, Atmos. Res., 158-159, 66-78, https://doi.org/10.1016/j.atmosres.2015.02.003, 2015a.

Zhao, R., Lee, A. K. Y., Huang, L., Li, X., Yang, F., and Abbatt, J. P. D.: Photochemical processing of aqueous atmospheric brown carbon, Atmos. Chem. Phys., 15, 6087-6100, https://doi.org/10.5194/acp-15-6087-2015, 2015 b.

Zong, Z., Wang, X., Tian, C., Chen, Y., Qu, L., Ji, L., Zhi, G., Li, J., and Zhang, G.: Source apportionment of $\mathrm{PM}_{2.5}$ at a regional background site in North China using PMF linked with radiocarbon analysis: insight into the contribution of biomass burning, Atmos. Chem. Phys., 16, 11249-11265, https://doi.org/10.5194/acp-16-11249-2016, 2016. 